\title{
Resiliensi Komunitas Mahasiswa Eks-Hizbut Tahrir Indonesia di Universitas Islam Negeri Sunan Ampel Surabaya Pasca-Perppu Nomor 2 Tahun 2017
}

\author{
Almi Novita \\ Universitas Islam Negeri Sunan Ampel Surabaya, Indoensia \\ almialminovita@gmail.com \\ Ainur Rofiq Al-Amin \\ Universitas Islam Negeri Sunan Ampel Surabaya, Indoensia \\ ar.alamin1972@gmail.com \\ Muchammad Helmi Umam \\ Universitas Islam Negeri Sunan Ampel Surabaya, Indoensia \\ helmi.umam@uinsby.ac.id
}

\begin{abstract}
Hizbut Tahrir Indonesia (HTI) was officially disbanded in 2017 by the government accordance with Perppu No.2 of 2017. The ex-Hizbut Tahrir Indonesia (HTI) did not immediately dissolve their movement, but more massive preaching of Islamic law within the framework of the caliphate in various regions especially on campus. The ex-Hizbut Tahrir Indonesia continue to recruit members by conducting various routine studies of Islam, such as the MALKIS study (Study of Exist Sunday Night) which is routinely carried out by the ex-Hizbut Tahrir Indonesia student community at UIN Sunan Ampel Surabaya. The purpose of this research to know and analyze the development and resilience of the ex-Hizbut Tahrir Indonesia student community after was disbanded in the UIN Sunan Ampel campus. This article uses descriptive qualitative research methods to present data and reveal events or facts. The results showed that the resilience of the ex-Hizbut Tahrir Indonesia (HTI) student community at UIN Sunan Ampel Surabaya could rise and come out of a stressful after was disbanded.
\end{abstract}

Keywords: Hizbut Tahrir Indonesia, Post disbanded, resilience 


\begin{abstract}
Abstrak
Hizbut Tahrir Indonesia (HTI) telah resmi dibubarkan pada Tahun 2017 oleh pemerintah sesuai Perppu Nomor 2 Tahun 2017. Pengikut eks Hizbut Tahrir Indonesia (HTI) tidak serta merta langsung membubarkan gerakannya, justru semakin masif mendakwahkan syariat Islam dalam bingkai khilafah di berbagai daerah khususnya dalam lingkup kampus. Pengitkut eks-Hizbut Tahrir Indonesia tetap melakukan rekrutmen anggota dengan mengadakan berbagai kajian rutin, seperti kajian MALKIS (Malam Minggu Kajian Eksis) yang rutin dilaksanakan komunitas mahasiswa eks-Hizbut Tahrir Indonesia di UIN Sunan Ampel Surabaya. Tujuan dari penelitian ini adalah untuk mengetahui perkembangan dan resiliensi komunitas mahasiswa eks-Hizbut Tahrir Indonesia pasca dibubarkan di lingkungan kampus UIN Sunan Ampel Surabaya. Artikel ini menggunakan metode penelitian kualitatif deskriptif untuk menyajikan data dan mengungkapkan kejadian atau fakta yang terjadi. Hasil penelitian menunjukan bahwa resiliensi komunitas mahasiswa eks-Hizbut Tahrir Indonesia (HTI) di Universitas Islam Negeri Sunan Ampel Surabaya dapat bangkit dan keluar dari keadaan stressfull pasca dibubarkan.

Kata kunci: Resiliensi, Hizbut Tahrir Indonesia, Pasca-Pembubaran
\end{abstract}

\title{
Pendahuluan
}

Islam di Indonesia merupakan agama mayoritas terbesar di dunia. Hal ini dibuktikan dengan data sensus penduduk pada tahun 2010 dimana sekitar $87,18 \%$ atau sekitar 207 juta masyarakat Indonesia beragama Islam. Dengan dmeikian, Islam memiliki ruang ekspresi yang kaya dalam menyebarkan setiap ajarannya sesuai dengan ajaran yang telah disampaikan Rasulullah SAW. Namun, tidak mudah untuk dapat menerapkan setiap ajaran yang disampaikan oleh Rasulullah SAW, karena konteks zaman yang berbeda. Maka dari itu, perlu adanya pengkajian dan pemahaman lebih dalam mengenai berbagai hal yang terjadi saat ini agar dapat sesuai dengan al-Quran dan Sunah.

Indonesia yang dikenal negara dengan mayoritas beragama Islam memiliki peluang yang cukup besar bagi para Organisasi Masyarakat (Ormas) Muslim untuk tumbuh subur dan memiliki banyak pendukung dari masyarakat yang sama-sama ingin menjalankan kehidupannya sesuai dengan syariat Islam. Salah satunya ialah Hizbut Tahrir. Hizbut Tahrir yang berarti partai pembebasan didirikan oleh seorang ulama Yerussalem (Lebanon) yang bernama Taqiyuddin an-Nabhani pada tahun 1953. Hizbut Tahrir tidak termasuk sebagai organisasi sosial keagamaan, melainkan sebagai partai politik yang bertujuan untuk membebaskan Islam dari lingkaran politik yang tidak berlandaskan syariat Islam (Turmudi \& Sihbudi, 2005, hal. 265-266). 
Dalam mengembangkan komunitasnya, Hizbut Tahrir membutuhkan suatu negara yang dapat memberikan banyak dukungan sehingga nantinya dapat merealisasikan misi yang dimiliki Hizbut Tahrir yakni menegakkan syariah Islam melalui sistem pemerintahan khilafah. Sejak awal masuknya Hizbut Tahrir ke Indonesia komunitas ini sudah memiliki strategi yang bisa mendukung penyebarannya di Indonesia, salah satunya adalah dengan masuk ke dalam lini-lini lembaga dakwah dan kalangan-kalangan yang bisa dipengaruhi (Qohar \& Haqiqi, 2017, hal. 366). Tujuan utama dari strategi dan dakwah yang secara rutin disampaikan oleh anggota komunitas Hizbut Tahrir Indonesia adalah untuk memberikan pemahaman secara mendalam kepada masyarakat dan para mahasiswa akan urgensi penyatuan dunia dengan menegakkan Khilafah Islamiyah. Oleb sebab itu, pada setiap kajian yang dilakukan selalu menyertakan isu khilafah, karena khilafah dianggap dan diyakini sebagai solusi dari setiap permasalahan yang ada dalam masyarakat. Bagi Hizbut tahrir Indonesia keadaan umat saat ini sudah sangat tidak islami, mengingat dampak sekularisme yang begitu kuat dikalangan milenial khususnya mahasiswa sehingga memiliki andil yang cukup besar dalam merubah pola pikir masyarakat dalam menciptakan kondisi masyarakat yang sangat buruk, sehingga memunculkan berbagai permasalahan dan pelanggaran yang kini tidak dapat ditegakkan baik melalui hukum pidana maupun perdata (Qohar \& Haqiqi, 2017).

Pasca dikeluarkannya Perppu mengenai pembubaran Hizbut Tahrir Indonesia pada tahun 2017 oleh Kementerian Hukum dan HAM, awalnya para simpatisan Hizbut Tahrir Indonesia mengajukan banding kepada Pengadilan Tinggi Tata Usaha Negara (PTTUN) namun pada akhirnya pengajuan banding tersebut ditolak karena putusan PTTUN yang menyatakan bahwa surat keputusan pembubaran Hizbut Tahrir Indonesia yang dikeluarkan oleh Kementerian Hukum dan HAM telah Sah (T. C. Indonesia, 2018). Meskipun pengajuan bandingnya ditolak, simpatisan eks-Hizbut Tahrir Indonesia tetap berusaha menggiring opini publik bahwa Khilafah Islamiyah merupakan salah satu syariat Islam yang harus ditegakkan dalam suatu negara, karena jika Khilafah Islamiyah tidak ditegakkan, maka dianggap sebagai kekafiran (Rikza, n.d., hal. 1-2).

Sistem negara versi Hizbut Tahrir Indonesia biasa disebut dengan khilafah merupakan salah satu kampanye dari pemikiran Hizbut Tahrir Indonesia yang paling mainstream bahkan menjadi penopang dari eksistensi dan perjuangan Hizbut Tahrir Indonesia. Hizbut Tahrir Indonesia masuk dan 
mempengaruhi masyarakat khususnya kaum milenial melalui pemikiran teologi, usul al-fiqh, sosial kemasyarakatan, politik dan berbagai pemikiran lainnya. Tidak cukup di situ, penyebaran ideologi Hizbut Tahrir Indonesia di kalangan milenial juga akan jauh lebih mudah karena berbentuk komunitas (Muhammadin, 2016, hal. 367).

Pasca resmi dibubarkan, komunitas eks-Hizbut Tahrir Indonesia berkembang pesat terutama di kalangan mahasiswa, bahkan sejak dibubarkan banyak dari masyarakat khususnya mahasiswa yang ingin mengetahui lebih dalam mengenai Hizbut Tahrir Indonesia. Hal ini dapat di buktikan dengan semakin banyak masyarakat yang mengikuti kajian rutin yang diadakan oleh simpatisan eks-Hizbut Tahrir Indonesia. Strategi yang digunakan Hizbut Tahrir Indonesia masih sama seperti sebelum dibubarkan yakni melakukan pembinaan melaui halaqah, berinteraksi dengan umat, dan memanfaatkan peluang politik. Mengetahui resiliensi dari komunitas eks-Hizbut Tahrir Indonesia adalah melalui tipe resiliensi. Melalui tipe-tipe resiliensi inilah yang kemudian nantinya dijadikan sebagai kajian strategi untuk dapat memberikan indikasi bahwa komunitas eks-Hizbut Tahrir Indonesia resilien dalam menyebarkan ide-idenya.

Sistem khilafah dianggap sebagai solusi dan komunitas eks-Hizbut Tahrir Indonesia akan tetap menolak bentuk negara demokrasi yang berideologi pancasila, karena dianggap bahwa pancasila tidak didasarkan pada prinsip Islam, walaupun sepintas tampak Islami. Hal ini dapat dilihat dalam aturan negara yang tidak mengakomodasi ajaran Islam secara totalitas. Alasan inilah yang kemudian membuat para simpatisan eks-Hizbut Tahrir Indonesia sangat resiliendalam menyebarkan ide-ide khilafah sesuai dengan Syariat Islam. Oleh karena itu, penelitian mengenai resistensi komunitas mahasiswa eks-Hizbut Tahrir Indonesia di UIN Sunan Ampel Surabaya pasca-Perppu nomor 2 tahun 2017 menarik untuk dilakukan.

\section{Metode}

Metode yang digunakan dalam penelitian ini adalah metode penelitian kualitatif deskriptif. Penelitian kualitatif deskriptif merupakan sebuah metode pengumpulan data yang memanfaatkan data kualitatif yang kemudian dijelaskan secara deskriptif. Dalam penelitian ini, proses pengumpulan data menggunakan observasi, wawancara, serta mengumpulkan data dari berbagai sumber yang dapat dipertanggungjawabkan, sepeti: buku, jurnal, artikel, skripsi, dan media lainnya. Observasi peneliti lakukan dengan mengikuti 
berbagai kajian yang diadakan komunitas eks-Hizbut Tahrir Indonesia, salah satunya adalah kajian "MALKIS" yang rutin diadakan setiap hari sabtu malam. Selain itu, sesekali peneliti melakukan wawancara dengan simpatisan eksHizbut Tahrir Indonesia dalam rangka menggali data dan fakta. Bermula dari observasi inilah yang kemudian menghasilkan data mengenai perkembangan dan resiliensi simpatisan eks-Hizbut Tahrir Indonesia Pasca-Pembubaran. Dan peneliti juga melakukan interpretasi makna yang terkandung dalam setiap dakwah dalam kajian-kajian yang disampaikan komunitas eks-Hizbut Tahrir Indonesia.

\section{Sejarah Masuknya HTI di UIN Sunan Ampel Surabaya}

Hizbut Tahrir Indonesia mulai masuk ke Surabaya sekitar tahun 90-an, di mana pada saat itu sebagian besar anggota dari Hizbut Tahrir Indonesia adalah mahasiswa yang berasal dari berbagai Universitas yang tersebar di Surabaya. Sejak awal kedatangannya, Hizbut Tahrir Indonesia selalu melakukan kaderisasi di berbagai universitas yang ada di Indonesia, sasaran awal Hizbut Tahrir Indonesia untuk dijadikan kader adalah para kalangan terdidik yang dapat mengubah pola pikir masyarakat yakni dari kalangan mahasiswa yang berasal dari universitas terkemuka. pengkaderan pertama Hizbut Tahrir Indonesia di Surabaya bertempat di Universitas Airlangga (UNAIR). Kemudian berlanjut ke Institut Tekhnologi Sepuluh November (ITS), Universitas Surabaya (UBAYA), Universitas Negeri Surabaya (UNESA), Universitas Islam Negeri Sunan Ampel (UINSA), dan kampus-kampus lainnya (Zakki, 2007, hal. 55).

Menurut pemaparan Ainur Rofiq Al-Amin, seorang eks anggota Hizbut Tahrir Indonesia yang saat ini telah menjadi Dosen Fakultas Aqidah dan Filsafat Islam di UIN Sunan Ampel Surabaya. Hizbut Tahrir Indonesia masuk ke UIN Sunan Ampel Surabaya sekitar tahun 1996 yang dipelopori oleh seorang mahasiswa Fakultas Syariah dan Hukum yang bernama Nasir. Awal mula masuknya Hizbut Tahrir Indonesia ke UIN Sunan Ampel Surabaya, Nasir tidak serta merta langsung mendirikan sebuah halaqah, ia memulainya dengan berdakwah kepada teman-teman terdekatnya dan mengajak mereka untuk mengikuti kajian rutin Hizbut Tahrir Indonesia di kampus Universitas Airlangga tempat pertama kali ia terdoktrin faham khilafah yang menjadi ideologi Hizbut Tahrir Indonesia bersama kakaknya yang bernama Irwan Syaifullah. 
Seiring dengan semakin berkembangnya simpatisan Hizbut Tahrir Indonesia di UIN Sunan Ampel Surabaya, mereka mulai mendirikan kajian di masjid Ulul Albab. Adapun motifnya ialah dengan dalih memperdalam ilmu agama, Hizbut Tahrir Indonesia mengajak para mahasiswa untuk mengikuti kajian yang rutin mereka adakan di masjid Ulul Albab, selain mengadakan kajian, Hizbut Tahrir Indonesia juga menempatkan beberapa dari simpatisan Hizbut Tahrir Indonesia untuk dapat menduduki peran penting yang ada di kampus, sehingga nantinya dianggap dapat berpengaruh pada perkembangan Hizbut Tahrir Indonesia. Hizbut Tahrir Indonesia mulai memasukkan kaderkadernya ke berbagai lembaga dakwah kampus, menjadi dosen, bahkan dokter yang bertugas di klinik UIN Sunan Ampel disinyalir merupakan seorang kader Hizbut Tahrir Indonesia (Al-Amin, n.d.). Namun, pasca-dibubarkan oleh pemerintah, penyebarannya kian hati-hati, Hizbut Tahrir Indonesia tak lagi frontal dalam menyebarkan ideologinya, mengingat Hizbut Tahrir Indonesia dianggap sebagai komunitas yang memiliki faham radikal maka penyebarannya dilarang oleh pemerintah khususnya di area sekitar kampus. Beberapa dosen yang dianggap terafiliasi Hizbut Tahrir Indonesia mulai dikeluarkan oleh kampus dan mahasiswa yang terindikasi terpapar ideologi khilafah juga mulai di pantau aktivitasnya. Penyebarannya di sekitar kampus kini terbatas, para simpatisan eks-Hizbut Tahrir Indonesia tidak lagi dapat menyelenggarakan kajian rutin di masjid Ulul Albab. Kini mereka tetap mengadakan kajian rutin namun di tempat khusus yang tertutup tidak lagi di sekitar kampus tetapi berada di luar kampus.

\section{Dinamika Pembubaran Ormas Hizbut Tahrir Indonesia}

Peraturan pemerintah pengganti undang-undang atau yang biasa kita sebut dengan Perppu Nomor 2 Tahun 2017 merupakan perubahan atas undangundang Nomor 17 Tahun 2013 mengenai organisasi kemasyarakatan yakni perppu pembubaran ormas yang telah ditanda tangani oleh Presiden Joko Widodo pada tanggal 10 Juli 2017. Pada saat itu, Undang-undang tentang ormas baru saja berumur 4 tahun dan secara komprehensif belum mengatur mengenai ormas yang bertentangan dengan Undang-Undang Dasar Republik Indonesia tahun 1945 dan Pancasila (Kurniawan, 2018, hal. 466). Diterbitkannya Peraturan Pemerintah Pengganti Undang-Undang (Perppu) Nomor 2 Tahun 2017 bukanlah tanpa alasan, Perppu ini dikeluarkan oleh pemerintah karena kondisi kegentingan yang memaksa. Mengingat saat ini Negara sedang dalam kondisi darurat Ormas yang dianggap dapat memecah 
belah Negara Kesatuan Republik Indonesia (NKRI) dengan berkembangnya faham radikalisme, separatisme, dan intoleran serta ormas-ormas yang mengkampanyekan ideologi anti Pancasila dan anti demokrasi. Maka dari itu perlu adanya hukum yang menindak tegas ormas-ormas yang menyimpang dari ideologi Negara Kesatuan Republik Indonesia (Permaqi, 2017, hal. 408).

Perppu ini juga bertujuan untuk mendeskripsikan ulang bagaimana tata cara berorganisasi yang benar sesuai dengan peraturan yang ada dalam Negara Kesatuan Republik Indonesia, sebagai penyelesaian bagi Ormas-ormas yang melanggar dan sanksi yang diberikan bagi Ormas yang melanggar ketentuan Undang-Undang. Setiap Ormas harus patuh terhadap Pancasila dan UUD Republik Indonesia Tahun 1945. Karena ideologi-ideologi yang ada dalam Hizbut Tahrir Indonesia dianggap telah melanggar ketentuan yang ada dalam UUD Republik Indonesia tahun 1945, dan dianggap dapat menyebarkan ideologi-ideologi yang dapat memecah belah bangsa Indonesia maka tidak lama setelah Pemerintah mensahkan Perppu Nomor 2 Tahun 2017 tentang Ormas, surat keterangan terdaftarnya Hizbut Tahrir Indonesia sebagai Ormas resmi dicabut oleh badan hukum dan menteri Hukum dan Ham tanpa adanya proses pengadilan (Pratiwi, 2017, hal. 289).

\section{Perkembangan eks HTI di kalangan Mahasiswa UIN Sunan Ampel Surabaya}

Hizbut Tahrir Indonesia resmi dibubarkan pada tahun 2017 oleh pemerintah bersamaan dengan Perppu yang telah disahkan oleh Presiden. Resmi dibubarkan bukan berarti penyebaran ideologinya ikut berhenti, para simpatisan eks-Hizbut Tahrir Indonesia terus berusaha menggunakan cara lain agar dapat tetap mendakwahkan dan terus menyebarkan setiap ilmu yang mereka dapat ketika mengaji kitab-kitab Hizbut Tahrir Indonesia melalui kajian-kajian yang diselenggarakan komunitas eks-Hizbut Tahrir Indonesia dan diskusi tentang pemikiran yang biasanya dilakukan di kampus-kampus yang ada di Indonesia (halaqah).

Pasca-dibubarkan Hizbut Tahrir Indonesia bertransformasi menjadi komunitas Royatul Islam (KARIM) (El-Saha, 2019). Hal demikian dilakukan karena mereka tidak dapat lagi menyebutkan Hizbut Tahrir Indonesia secara terang-terangan dalam setiap kegiatannya karena statusnya yang kini telah menjadi Ormas terlarang di Indonesia. Namun, meskipun Hizbut Tahrir Indonesia kini menjadi Ormas terlarang, mereka tetap mengadakan berbagai kajian rutin yang diadakan di berbagai wilayah dan kampus-kampus yang ada di Indonesia khususnya di Surabaya. Dalam kajian-kajian dan diskusi-diskusi 
yang mereka adakan, mereka tidak lagi menamakan kajiannya sebagai kajian dari Hizbut Tahrir Indonesia dan kajian yang disampaikan tidak selalu membahas mengenai Khilafah. Materi-materi yang biasanya dibahas ketika kajian adalah hal-hal yang berhubungan dengan Akidah dan permasalahanpermasalahan yang sedang menjadi trending topic sehingga menggugah ketertarikan masyarakat untuk ikut bergabung mengikuti kajian rutin tersebut.

Beberapa contoh yang sedang ramai diperbincangkan adalah mengenai nyanyian yang berjudul "Entah apa yang merasukimu?", kemudian komunitas eks-Hizbut Tahrir Indonesia yang ada di UIN Sunan Ampel Surabaya mengadakan kajian dengan mengusung tema tersebut, sehingga membuat para simpatisan yang hadir menjadi tertarik untuk mengikuti kajian yang diadakan oleh komunitas eks-Hizbut Tahrir Indonesia yang ada di UIN Sunan Ampel Surabaya. Materi yang disampaikan oleh seorang mahasiswi tingkat akhir yang sepertinya sudah lama bergabung menjadi anggota eks-Hizbut Tahrir Indonesia terlihat sudah sangat ahli dalam menyampaikan materi, terutama mengenai hal-hal yang berhubungan dengan politik yang gencar dibahas ialah penggantikan ideologi Pancasila ke sistem khilafah dan dianggap sesuai dengan sistem pemerintahan yang ada dalam Islam, sehingga dalam setiap kajiannya selalu ada pembahasan yang berkaitan dengan kritik terhadap pemerintahan yang ada saat ini.

Bahkan dalam kajian yang berjudul "Entah apa yang merasukimu?" pada tanggal 14 September 2019 secara terang-terangan pemateri menyinggung para menteri Indonesia dan para pemimpin daerah yang sedang marak melakukan korupsi besar-besaran, Sehingga pemerintahan saat ini telah ternodai atas perbuatan para koruptor. Kemudian di akhir pembahasan pemateri menyampaikan ideologi Hizbut Tahrir Indonesia yakni khilafah sebagai suatu sistem pemerintahan yang sesuai dengan Islam yang dapat menjadi solusi dan seharusnya dapat di tegakkan di seluruh negara. Karena hanya pemerintahan dengan sistem khilafah-lah pemerintah akan bebas dari korupsi (Titel bukan ukuran keimanan seseorang, n.d.).

Pasca-dibubarkan hal-hal menarik yang berhasil peneliti temukan sebagai bukti bahwa komunitas eks-Hizbut Tahrir di UIN Sunan Ampel Surabaya masih terus mengembangkan komunitasnya adalah: Pertama, komunitas mahasiswa eks-Hizbut Tahrir Indonesia di UIN Sunan Ampel Surabaya masih mengadakan kajian rutin setiap hari sabtu malam kajian "MALKIS" di sebuah kontrakan yang tertutup. Kedua, masih masif merekrut mahasiswa lainnya melalui kajian yang diadakan setiap sabtu malam atau 
hanya sekedar untuk berkunjung ke sebuah kosan yang dihuni oleh para simpatisan eks-Hizbut Tahrir Indonesia. Ketiga, dalam setiap dakwah yang disampaikan masih mengusung ide Khilafah Islamiyah sebagai solusi dalam menghadapi setiap permasalahan yang dihadapi masyarakat saat ini. Keempat, para pengisi kajian rutin setiap minggu yang diadakan oleh komunitas eksHizbut Tahrir Indonesia di UIN Sunan Ampel Surabaya di dominasi oleh mahasiswi S2 dan senior yang sudah sejak lama menjadi anggota Hizbut Tahrir Indonesia. Kelima, simpatisan eks-Hizbut Tahrir Indonesia masih membagikan buletin yang biasa dibagikan setiap hari Jum'at setelah shalat Jum'at di masjid-masjid yang ada di Surabaya dan juga biasa dibagikan setelah mengikuti kajian-kajian yang mereka adakan. Keenam, bagi yang terafiliasi sebagai anggota Hizbut Tahrir Indonesia di berhentikan dari kampus. Hal ini dapat dibuktikan dengan adanya seorang dosen yang terafiliasi Hizbut Tahrir Indonesia dikeluaran oleh kampus sejak satu semester terakhir, pada tahun 2019.

Meskipun dalam setiap kajiannya tidak mengakui komunitasnya sebagai komunitas eks-Hizbut Tahrir Indonesia namun isu-isu yang kuat mengenai khilafah sebagai solusi, dan berbagai kritik yang dilayangkan kepada pemerintah masih sering di bahas dalam setiap kajian yang mereka adakan. Hal inilah yang penulis yakini bahwa komunitas eks-Hizbut Tahrir Indonesia masih masif mengembangkan komunitasnya. Dan orang-orang yang terlibat dalam kajian tersebut dapat dilacak keberadaannya dan tersambung dengan anggota eks-Hizbut Tahrir Indonesia lainnya.

Pembubaran Hizbut Tahrir Indonesia juga nampaknya tidak begitu berpengaruh pada setiap aktifitas dakwahnya di berbagai daerah yang ada di Indonesia. Hal ini dibuktikan dengan adanya berbagai kajian rutin seperti sohib yang hingga saat ini masih ada dan dalam setiap kajiannya dihadiri oleh banyak masyarakat terutama mereka yang sedang memperdalam ilmu agama. Selain kajian yang masih rutin diselenggarakan di berbagai daerah, komunitas eksHizbut Tahrir Indonesia juga masih menerbitkan majalah dan buletin mingguan yang dibagikan setiap hari jumat baik secara offline maupun online yang biasa diterbitkan melalui Tsaqafah.id ataupun instagram melalui akun Buletin dakwah kaffah. Komunitas eks-Hizbut Tahrir Indonesia juga mengngikuti perkembangan zaman, mereka aktifberdakwah secara online baik melalui instagram, youtube, whatsapp, dan media sosial lainnya (S. eks H. T. Indonesia, 2019). 
Berbeda dengan aktivitas dakwah yang diadakan di berbagai daerah yang ada di Indonesia, pembubaran Hizbut tahrir Indonesia justru sangat berpengaruh pada aktivitas dakwah yang dilakukan para mahasiswa simpatisan eks-Hizbut Tahrir Indonesia hampir di seluruh kampus yang ada di Indonesia. Hal ini dikarenakan aktivitasnya yang sangat di pantau oleh pihak kampus sesuai dengan himbauan pemerintah, karena dikhawatirkan dapat menyebarkan unsur-unsur yang mengandung faham radikalisme kepada mahasiswa lainnya terutama bagi mahasiswa baru yang belum begitu faham mengenai aktivitas-aktivitas yang mengandung unsur radikalisme (Affan, 2017).

Namun hal demikian tidak menjadi penghalang bagi komunitas eksHizbut Tahrir Indonesia dalam berdakwah, karena bagi komunitas eks-Hizbut Tahrir Indonesia sebagai umat Islam yang taat kita tidak boleh berhenti berdakwah, karena dakwah merupakan penyadaran umat akan urgensinya untuk kembali pada kehidupan yang Islami dan mewujudkan khilafah merupakan kewajiban yang tidak bisa lagi ditawar dalam Hizbut Tahrir Indonesia. khilafah is the most pivotal action yang harus segera direalisasikan, bahkan khilafah bisa dikatakan lebih utama dari pada masalah akidah, karena khilafah merupakan persoalan hidup dan mati. Dakwah yang saat ini sedang di lakukan oleh para simpatisan eks-Hizbut Tahrir Indonesia merupakan dakwah untuk melanjutkan kehidupan Islam dan sebagai sebuah upaya untuk mewujudkan daulat Islam yang dapat menerapkan hukum Islam secara menyeluruh (Al-Amin, 2017, hal. 73). Berikut QS. al-Baqarah: 30 yang sering disebutkan dalam kajian-kajian eks-Hizbut Tahrir Indonesia dan biasa dijadikan sebagai landasan dalam menegakkan khilafah, Allah berfirman:

"Dan (ingatlah) ketika Tuhanmu berfirman kepada para malaikat, "aku hendak menjadikan khalifah di bumi". Mereka berkata, "Apakah Engkau hendak menjadikan orang yang merusak dan menumpahkan darah disana, sedangkan kami bertasbih memuji-Mu dan menyucikan nama-Mu?" Dia berfirman, Sungguh, Aku mengetahui apa yang tidak kamu ketahui".

Selain menggunakan Ayat al-Quran sebagai landasannya, komunitas eks-Hizbut Tahrir Indonesia juga menggunakan beberapa hadis dalam upaya meyakinkan masyarakat akan penegakkan Syariat Islam dalam bingkai khilafah, berikut salah satu hadis yang disampaikan dalam kajian MALKIS yang dianggap sebagai pesan yang disampaikan oleh Rasulullah SAW sebelum beliau wafat. Bahwa kepemimpinan yang tadinya dipimpin oleh Nabi, pasca wafatnya Nabi akan digantikan oleh seorang khalifah sebagai pemimpin. Hadits tersebut 
kemudian dianggap sebagai kabar yang disampaikan oleh Nabi yang mengandung pujian atas hadirnya khilafah.

"Nabi bersabda, "Dulu Bani Israil diurus dan dipimpin oleh Nabi. Setiap seorang Nabi meninggal, akan digantikan dengan Nabi yang lain. Sesungguhnya tidak ada Nabi setelahku, dan aku ada banyak khalifah, "para sahabat bertanya: lalu apa yang Engkau perintahkan kepada kami?" Rasulullah SAW bersabda, penuhilah baiat yang pertama, yang pertama saja, dan berikanlah kepada mereka haknya. Sesungguhnya Allah akan meminta kepada mereka pertanggungjawaban atas apa yang mereka lakukan" (Al-Amin, 2019, hal. 18).

Dalam sebuah jurnal yang berjudul "Hadis Khilafah dan Relasinya Terhadap Kontestasi Politik Hizbut Tahrir Indonesia Pasca-Perppu Nomor 2 Tahun 2017" menjelaskan bahwa pada saat Rasulullah SAW wafat, beliau sama sekali tidak memberikan instruksi mengenai pemimpin selanjutnya yang akan menggantikan dirinya, mengingat Nabi Muhammad merupakan nabi terakhir dan menjadi penutup para Nabi.

Hal demikian kemudian menimbulkan perselisihan terkait siapa pengganti Nabi sebagai pemimpin. Kemudian Al-Mawardi mencatat transmisi kepemimpinan mulai dari satu khilafah ke khilafah lainnya, melalui shura, wasiat, ahl al-hal wa al-'aqd, hingga baiat. Meskipun demikian, pada akhirnya untuk menentukan seorang pemimpin ditekankan melalui musyawarah. Kemudian setelah periode tersebut barulah sistem kekuasaan diperebutkan melalui kudeta, secara berdarah-darah dan diwariskan dalam format dinasti. Sehingga dapat kita pahami bahwa Islam sangat terbuka bagi segala macam suksesi, termasuk sistem demokrasi yang saat ini digunakan di Indonesia. Meski demikian, Hizbut Tahrir Indonesia tetap merindukan kejayaan Islam sebagaimana pada masa kejayaan khulafa al-Rashidin dan masa pemerintahan Umar bin Abd al-aziz, mengingat masa kekhilafahan yang terbaik berasal dari dinasti umayyah dan kekhilafahan Umar selalu dijadikan sebagai model khilafah yang ideal (Rikza, n.d.).

Secara keseluruhan, baik sebelum dibubarkan maupun setelah dibubarkan. Strategi komunitas eks-Hizbut Tahrir Indonesia dalam menegakkan Khilafah Islamiyah tetaplah sama, hanya saja saat ini komunitas eks-Hizbut Tahrir Indonesia tidak mengatasnamakan setiap kegiatannya sebagai komunitas Hizbut Tahrir Indonesia dan mereka lebih tertutup meskipun kajian yang diadakannya bersifat umum. Hal demikian dikarenakan komunitasnya yang hingga saat ini masih dipantau khususnya disekitar 
kampus, karena dianggap dapat menyebarkan faham radikalisme yang dapat memecah belah Negara Kesatuan Republik Indonesia (NKRI). Maka dari itu, komunitas mahasiswa eks-Hizbut Tahrir Indonesia yang ada di UIN Sunan Ampel Surabaya lebih tertutup pasca-dibubarkan, karena mahasiswa ataupun staf kampus yang terafiliasi eks-Hizbut Tahrir Indonesia dapat dikeluarkan dari kampus, hal ini terbukti dengan adanya seorang dosen yang terafiliasi Hizbut Tahrir Indonesia dikeluarkan dari kampus UIN Sunan Ampel Surabaya sejak tahun 2019.

\section{Resiliensi Komunitas Mahasiswa Eks-Hizbut Tahrir Indonesia di UIN Sunan Ampel Surabaya}

Setelah dibubarkan komunitas mahasiswa eks-Hizbut Tahrir Indonesia masih melakukan berbagai gerakan yang disinyalir memuat unsur resiliensi, diantaranya adalah gerakan dakwah, ekonomi, pendidikan, dan lain sebagainya.

Gerakan yang pertama adalah gerakan dakwah. Komunitas eks-Hizbut Tahrir Indonesia yang tersebar di seluruh kampus yang ada di Indonesia masih sangat aktif melakukan dakwah baik kepada masyarakat sekitar maupun melalui forum kajian yang masih mereka dirikan di sekitar kampus melalui halaqah dan melakukan pendekatan kepada teman-teman yang mereka jumpai di sekitar kampus. Meskipun ada himbuan dari pemerintah kepada sejumlah perguruan tinggi yang ada di Indonesia untuk mulai melarang dan meniadakan segala kegiatan yang terafiliasi Hizbut Tahrir Indonesia dilaksanakan di sekitar kampus. Mengingat posisi perguruan tinggi yang sangat strategis untuk menerapkan ideologi khilafah yang dianggap bertentangan dengan ideologi negara Indonesia yakni pancasila, maka para pimpinan yang ada di seluruh perguruan tinggi di Indonesia diminta untuk dapat mengidentifikasi simbolsimbol radikalisme yang masuk kedalam berbagai kegiatan yang ada di kampus (Affan, 2017).

Namun dengan resiliensi yang sangat kuat, membuat komunitas mahasiswa eks-Hizbut Tahrir Indonesia yang ada di kampus UIN Sunan Ampel Surabaya masih masif mendakwahkan ajarannya melalui halaqah di sebuah kosan yang tertutup. Kajian rutin yang dilaksanakan setiap hari Sabtu pukul 18.30 merupakan kajian malkis (Malam Minggu Kajian Eksis). Larangan mengadakan kegiatan dan ada menamakan Hizbut Tahrir Indonesia yang telah dibubarkan, maka komunitas eks-Hizbut Tahrir Indonesia tidak dapat menyebutkan komunitasnya secara gamblang, mengingat hingga saat ini 
aktivitasnya masih dipantau. Kelompok ini tidak hanya menyembunyikan identitasnya, tetapi juga tidak selalu membahas mengenai penegakkan khilafah dalam setiap kajiannya. Namun, melalui ajakan untuk menegakkan syariat Islam dan menjalankan ajaran Islam secara kaffah menjadi suatu bingkai menuju pemahaman akan penegakkan khilafah sebagai sistem bernegara yang sesuai dengan syariat Islam. Hal inilah yang kemudian disebut sebagai kajian dakwah yang dilakukan pada malkis dan merupakan kajian rutin komunitas mahasiswa eks-Hizbut Tahrir Indonesia di UIN Sunan Ampel Surabaya.

Pada wilayah berbeda, kelompok eks- Hizbut Tahrir Indonesia juga aktif melakukan gerakan penyebaran ideologinya yaitu bidang pendidikan. Banyak anggota eks-Hizbut Tahrir Indonesia yang berprofesi sebagai guru. Baik mengajar di sebuah lembaga pendidikan seperti sekolah maupun manjadi seorang tentor privat atau sebagai pengajar mengaji di sebuah TPQ. Hal ini penulis ketahui ketika melakukan wawancara bersama dengan salah seorang anggota eks-Hizbut Tahrir Indonesia yang menyebutkan bahwa dirinya dan banyak dari teman-teman sesama anggota eks-Hizbut Tahrir Indonesia menjadi seorang guru, tentor privat dan pengajar di salah satu TPQ yang ada di Surabaya. Di UIN Sunan Ampel sendiri diperkirakan ada beberapa dosen yang terafiliasi sebagai anggota eks-Hizbut Tahrir Indonesia, namun baru satu dosen yang diketahui terafiliasi sebagai anggota eks-Hizbut Tahrir Indonesia yang akhirnya dikeluarkan dan dicabut izin mengajarnya oleh pihak kampus. Komunitas eks-Hizbut Tahrir Indonesia tidak hanya semata-mata menempatkan anggotanya pada sektor pendidikan untuk bekerja, tetapi hal ini merupakan salah satu strategi yang dimiliki Hizbut Tahrir Indonesia agar dapat mempermudah menyebarkan ajarannya kepada masyarakat secara luas, karena posisi ini dianggap cukup strategis dalam usaha menerapkan syariat Islam kepada masyarakat (S. eks H. T. Indonesia, 2019).

Selain itu, komunitas eks-Hizbut Tahrir Indonesia juga membuat sebuah komunitas dakwah yang bergerak di bidang ekonomi, yakni: SOHIB (Sobat Hidup Berkah). Komunitas dakwah ini merupakan sebuah wadah yang sebagian besar materinya menjelaskan mengenai cara berdagang sebagaimana Rasulullah SAW. Komunitas sohib rutin mengadakan kajian setiap hari senin pukul 19.30 di tempat yang berpindah-pindah, terkadang di sebuah rumah makan, hotel, dan tempat-tempat perkumpulan lainnya yang ada di sekitar Surabaya dan Sidoarjo. Dalam kajian sohib berbagai kalangan ikut berkumpul, mulai dari remaja, mahasiswa, ibu rumah tangga, para pembisnis muda dan 
masih banyak lagi. Banyaknya minat masyarakat yang ingin memperdalam ilmu agama menjadi salah satu alasan komunitas eks-Hizbut Tahrir Indonesia tetap resilien untuk berdakwah mendakwahkan Syariat Islam kepada masyarakat luas melalui berbagai kajian yang dikemas secara menarik. Komunitas ini saya ketahui melalui salah seorang simpatisan eks-Hizbut Tahrir Indonesia pada saat mengikuti kajian malkis.

Melalui kajian-kajian yang mereka dirikan menjadi bukti bahwa komunitas eks-Hizbut Tahrir Indonesia resilien dan masif mendakwahkan ajarannya yakni penegakkan syariat Islam dalam bingkai Khilafah Islamiyah. Meskipun aktivitasnya dipantau dan resiko yang dihadapi komunitas eksHizbut Tahrir Indonesia di UIN Sunan Ampel Surabaya cukup besar, namun mereka yakin bahwa suatu saat Islam akan kembali berjaya bersamaan dengan tegaknya khilafah sebagai ideologi komunitas eks-Hizbut Tahrir Indonesia.

\section{Tipe Resiliensi komunitas Eks-Hizbut Tahrir Indonesia}

\section{Regulasi emosi}

Regulasi emosi merupakan sebuah kemampuan individu maupun kelompok untuk tetap tenang meskipun dalam keadaan stressfull atau tertekan. Dalam sebuah penelitian dijelaskan bahwa seseorang yang dapat mengendalikan emosinya akan berpengaruh pada lingkungan sekitarnya, sehingga jika seseorang dapat mengendalikan emosinya maka ia akan dapat menjalin hubungan yang baik dengan orang-orang yang ada disekitarnya (Septiani \& Fritria, 2016, hal. 64).

Resiliensi tipe ini digunakan komunitas eks-Hizbut Tahrir Indonesia ketika mereka mengalami tekanan pada saat dibubarkan. Meskipun para simpatisan eks-Hizbut Tahrir Indonesia tidak dapat menerima keputusan bahwa organisasinya dilarang dan resmi dibubarkan, banding yang mereka ajukanpun ditolak oleh pemerintah, namun dalam menyikapi hal ini mereka berusaha untuk dapat meregulasi emosinya dengan calming (tenang) dan focusing (fokus). Maka dari itu, dengan meregulasi emosinya komunitas eksHizbut Tahrir Indonesia semakin berkembang dan kajian-kajian rutin yang diadakan oleh komunitas eks-Hizbut Tahrir Indonesia tetap berjalan seperti sebelum dibubarkan. 


\section{Optimis}

Seorang individu maupun kelompok yang optimis akan selalu menganggap bahwa masa depannya cemerlang. Dengan adanya optimisme seseorang atau kelompok akan memiliki banyak harapan dan akan menumbuhkan rasa percaya bahwa ia dapat mewujudkan harapannya. Karena yang memegang kendali atas arah hidupnya adalah dirinya sendiri yang ditanam dan dibentuk dalam dirinya (Septiani \& Fritria, 2016). Optimis juga menjadi salah satu tipe resiliensi yang dimiliki komunitas eks-Hizbut Tahrir Indonesia. Hal ini penulis yakini melalui kajian yang disampaikan oleh simpatisan eks-Hizbut Tahrir Indonesia. Beberapa kali mereka menyampaikan keyakinannya untuk dapat mengembalikan kejayaan Islam seperti zaman Rasulullah SAW.Optimisme para simpatisan eks-Hizbut Tahrir Indonesia juga diperkuat dengan adanya beberapa ayat Al-Qur'an yang menjelaskan tentang tegaknya khilafah dan keharusan menjalankan agama secara menyeluruh (kaffah) sebagaimana dijelaskan dalam QS. al-Baqarah: 208, Allah SAW berfirman:

"Wahai orang-orang yang beriman, masuklah kedalam Islam secara keseluruhan, dan janganlah kamu mengikuti langkah-langkah setan. Sungguh ia musuh nyata bagimu."

Optimisme yang dimiliki komunitas eks-Hizbut Tahrir Indonesia menjadikan komunitasnya resilien untuk tetap berdakwah menyadarkan masyarakat akan pentingnya hidup sesuai dengan Syariat Islam demi terwujudnya pemerintahan dengan sistem khilafah. Namun, tidak semuanya yang di dakwahkan oleh Hizbut Tahrir Indonesia dapat kita terima begitu saja, perlu pengkajian yang lebih mendalam mengenai makna-makna yang terkandung dalam setiap kajian yang disampaikan eks-Hizbut Tahrir Indonesia.

\section{Self-Efficacy}

Self-Efficacy merupakan apresiasi dari sebuah keyakinan bahwa kita mampu menyelesaikan setiap permasalahan yang kita hadapi, dan kita dapat mencapai kesuksesan (Utami \& Helmi, 2017, hal. 56). Tipe dari resiliensi ini mempunyai pengaruh yang cukup besar dalam menyelesaikan permasalahanpermasalahan yang sedang dihadapi oleh komunitas eks-Hizbut Tahrir Indonesia. Permasalahan yang saat ini dihadapi simpatisan eks-Hizbut Tahrir Indonesia adalah terbatasnya ruang dakwah Hizbut Tahrir Indonesia karena dibubarkan oleh pemerintah dan strategi untuk menduduki tempat-tempat 
strategis di berbagai bidang pun sulit untuk terlaksana karena organisasinya kini ilegal. Maka Self-Efficacy penting untuk mereka gunakan sebagai bentuk resiliensi komunitas eks-Hizbut Tahrir Indonesia bahwa tertutupnya akses bukan berarti menghentikan gerakan dakwahnya demi tercapainya sebuah cita-cita.

\section{Causal Analysis}

Causal Analysis merupakan suatu kemampuan untuk dapat mengidentifikasi penyebab dari suatu permasalahan yang sedang dihadapinya secara akurat. Untuk dapat mengidentifikasi permasalahan tersebut dibutuhkan gaya berpikir explanatory, yakni: personal (saya-bukan saya), permanen (selalu-tidak selalu) dan pervasive (semua-tidak semua). Jika kita hubungkan dengan komunitas eks-Hizbut Tahrir Indonesia, maka komunitas ini cenderung memiliki gaya berpikir "Bukan Saya-Tidak Selalu-Tidak Semua", hal demikian dibuktikan dengan sebuah tindakan yang menyatakan bahwa dibubarkannya Hizbut Tahrir Indonesia bukan berasal dari ormasnya, melainkan dari orang-orang yang takut akan tegaknya khilafah (bukan saya), kondisi tersebut dapat diubah mengingat minat masyarakat untuk memperdalam ilmu agama yang masih masif (tidak selalu), dan dibubarkannya Hizbut Tahrir Indonesia tidak berdampak besar bagi perkembangan komunitasnya (tidak semua). Mereka yang memiliki gaya berpikir seperti ini cenderung dapat merumuskan permasalahan yang dihadapinya sehingga dapat dengan mudah menyelesaikan permasalahan yang dihadapinya (Septiani \& Fritria, 2016).

\section{Empati}

Salah satu prilaku yang dilakukan oleh seorang yang resilien adalah dengan menunjukan rasa empatinya (Septiani \& Fritria, 2016). Rasa empati yang diberikan oleh komunitas eks-Hizbut Tahrir Indonesia adalah dengan berdakwah kepada masyarakat sebagai bentuk keprihatinan Hizbut Tahrir Indonesia terhadap masyarakat yang kini telah jauh dari agama Allah dan kemaksiatan yang merajalela seakan-akan tidak takut akan azab Allah yang akan turun jika suatu kaum selalu berbuat maksiat. 


\section{Reaching out}

Reaching out merupakan sebuah cara untuk mendapatkan penglaman hidup agar dapat menjadi lebih bermakna. Resiliensi digunakan untuk menemukan makna dan tujuan dalam kehidupannya, maka komunitas eksHizbut Tahrir Indonesia dapat memperkirakan resiko yang akan ia hadapi dengan baik (Septiani \& Fritria, 2016). Berikut pemaparan salah seorang simpatisan eks-Hizbut Tahrir Indonesia mengenai Reaching Out.

"Kehidupan di dunia merupakan sebuah cara untuk mempersiapkan kehidupan kita di akhirat kelak. Kita diciptakan oleh Allah, maka dari itu tujuan hidup kita di dunia hanya untuk beribadah kepada Allah yakni mengajak pada kebaikan dan mencegah kemungkaran. Kita hidup harus sesuai dengan aturan Allah, jika kita hidup tidaksesuai dengan aturan Allah lalu untuk apa kita hidup? Di akhirat nanti kita akan ditempatkan di mana? surga ataukah neraka? nah jika kita ingin ditempatkan si surga maka kita harus menerapkan dan menjalankan setiap syariat Allah dengan melakukan amar ma'ruf nahyi munkar" (S. eks H. T. Indonesia, 2019).

\section{Cici-ciri Resiliensi Komunitas eks-Hizbut Tahrir Indonesia}

Pertama, pada saat dibubarkan eks-Hizbut Tahrir Indonesia masih resilien menjalankan dakwahnya di berbagai daerah. Hal inilah yang kemudian menjadi salah satu ciri bahwa komunitas Eks-Hizbut Tahrir Indonesia dapat bangkit dari keterpurukan yang sedang mereka alami.

Kedua, dapat mengatasi perubahan-perubahan yang terjadi dalam Organisasinya. Hal demikian dapat dibuktikan dengan cara bagaimana komunitas eks-Hizbut Tahrir Indonesia mengubah beberapa strategi dakwah melalui halaqah-halaqah yang mereka dirikan. Dari yang sejak awal diadakan secara terbuka di sekitar kampus, kini beralih ke sebuah kontrakan yang sangat tertutup.

Ketiga, memiliki rasa percaya yang sangat tinggi terkadap takdir. Dalam hal ini, komunitas Eks-Hizbut Tahrir Indonesia sangat yakin bahwa sesuai dengan janji Allah khilafah akan tegak dan Islam akan kembali berjaya, maka dari itu komunitas eks-Hizbut Tahrir Indonesia tidak akan menyerah dalam menjalankan dakwahnya sebagaimana dakwah Rasulullah SAW.

Keempat, dapat mempertahankan identitasnya walaupun dalam keadaan tersulit sekalipun. Meskipun dalam setiap kajiannya komunitas eksHizbut Tahrir Indonesia tidak pernah menyebutkan komunitasnya sebagai komunitas eks-Hizbut Tahrir Indonesia, namun mereka tetap 
mempertahankan identitasnya sebagai anggota eks-Hizbut Tahrir Indonesia dengan berdakwah demi tegaknya Syariah Islam dalam bingkai khilafah.

Kelima, Komunitas eks-Hizbut Tahrir Indonesia juga memiliki resiliensi yang tinggi sehingga cenderung easygoing, mudah bersosialisasi, dan memiliki keterampilan berpikir yang baik. Sehingga pada saat pemerintah mensahkan pembubaran Organisasinya, mereka langsung merancang strategi baru yang akan mereka gunakan pasca-dibubarkan, agar proses rekrutmen dan dakwah kepada masyarakat tetap berjalan (Azzahra, 2017, hal. 86)

\section{Simpulan}

Pasca resmi di bubarkan pada tahun 2017, Hizbut Tahrir Indonesia tidak serta merta membubarkan Organisasinya, namun kini mereka bertransformasi menjadi sebuah komunitas yang tersebar di seluruh Indonesia khususnya dalam lingkup kampus. Meskipun komunitasnya telah dinyatakan illegal, namun kegiatan rekrutmen dan kajian-kajian rutin sebagai aktivitas dakwah Hizbut Tahrir Indonesia masih terus berjalan. Hal demikin dibuktikan dengan adanya kajian "Malkis" yang terindikasi sebagai kajian rutin komunitas eksHizbut Tahrir Indonesia yang ada di UIN Sunan ampel Surabaya, karena di beberapa kesempatan pemateri kajian membahas mengenai Islam kaffah dan penegakkan khilafah sebagai solusi dari setiap permasalahan yang ada. Maka, adanya kajian tersebut menjadi salah satu bukti bahwa komunitas eks-Hizbut Tahrir Indonesia terus berkembang dan resilien. Resiliensi komunitas ini juga dapat dibuktikan dengan tipe dan ciri resiliensi yang sesuai dengan komunitas mahasiswa eks-Hizbut Tahrir Indonesia. 


\section{Referensi}

Affan, H. (2017). Kegiatan HTI mulai dilarang di sejumlah kampus, HTI protes.

Al-Amin, A. R. (n.d.). Wawancara.

Al-Amin, A. R. (2017). Khilafah HTI dalam Timbangan. Jakarta: Pustaka Harakatuna.

Al-Amin, A. R. (2019). Mematahkan argumentasi Hizbut Tahrir. Jakarta: Wahid Foundation.

Azzahra, F. (2017). Pengaruh Resiliensi Terhadap Distres Psikologis Pada Mahasiswa. Jurnal Ilmiah Psikologi Terapan, 5(1).

El-Saha, M. I. (2019). Komunitas Royatul Islam: Transformasi HTI?

Indonesia, S. eks H. T. (2019). Wawancara. Surabaya.

Indonesia, T. C. (2018). Banding Ditolak, HTI Ajukan Kasasi ke Mahkamah Agung.

Kurniawan, M. B. (2018). Konstitusional Perppu Nomor 2 Tahun 2017 tentang Ormas Ditinjau dari UUD 1945. Jurnal Konstitusi, 15(3).

Muhammadin. (2016). Relevansi Sistem Khilafah Hizbut Tahrir Indonesia (HTI) Dengan Sistem Negara Islam Modern. Intizar: Jurnal Kajian Keislaman dan Kemasyarakatan, 22(2).

Permaqi, F. (2017). Politik Hukum Pembentukan Peraturan Pemerintah Pengganti Undang-Undang dalam Asas Hal Ikhwal Kegentingan yang Memaksa. Jurnal Legislasi Indonesia, 14(4).

Pratiwi, D. K. (2017). Implikasi Yuridis Peraturan Pemerintah Pengganti Undangundang Nomor 17 Tahun 2013 Tentang Organisasi Kemasyarakatan di Indonesia. Padjajaran Jurnal Ilmu Hukum, 4(2).

Qohar, A., \& Haqiqi, K. M. (2017). Eksistensi Gerakan Ideologi Transnasional HTI Sebelum dan Sesudah Pembubaran. Kalam, 11(2).

Rikza, M. (n.d.). Hadis Khilafah dan Relasinya Terhadap Kontestasi. Mutawatir: Jurnal Keilmuan Tafsir Hadis.

Septiani, T., \& Fritria, N. (2016). Hubungan Antara Resiliensi dengan Stres pada Mahasiswa Sekolah Tinggi Kedinasan. Jurnal Penelitian Psikologi, 7(2).

Titel bukan ukuran keimanan seseorang. (n.d.).

Turmudi, E., \& Sihbudi, R. (2005). Islam dan Radikalisme di Indonesia. Jakarta: LIPI Press.

Utami, C. T., \& Helmi, A. F. (2017). Self-Efficacy dan Resiliensi: Sebuah Tinjauan Meta-Analisis. Buletin Psikologi, 25(1).

Zakki, A. (2007). Jaringan Hizbut Tahrir Indonesia. Institut Agama Islam Negeri Sunan Ampel Surabaya. 
This page intentionally left blank 